ISSN 0258-7122

Bangladesh J. Agril. Res. 37(4): 691-710, December 2012

\title{
PERFORMANCE OF TWELVE MANGO CULTIVARS GROWN IN DIFFERENT AGRO-ECOLOGICAL ZONES OF BANGLADESH
}

\author{
K. KOBRA ${ }^{1}$, M.A. HOSSAIN ${ }^{2}$, M.A.H. TALUKDER ${ }^{3}$ \\ M.A.J. BHUYAN ${ }^{4}$
}

\begin{abstract}
Twelve commercial and promising mango cultivars were evaluated at three agroecological zones of Bangladesh viz., Akbarpur (AEZ 29), Chapai Nawabgonj (AEZ 11), and Gazipur (AEZ 28) during 2006-07 to investigate their regional adaptability. Cultivars included in the experiment were Ashwina, BARI Aam-1, Bombai, Deori, Fazli, Gopalbhog, Kalia, Khirsapat, Langra, Lata Bombai, Rani Passand, and Surjapuri. The plants were transplanted in the field during July 1993. Tree volume was the maximum $\left(79.78 \mathrm{~m}^{3}\right)$ in Khirsapat and the minimum in Lata Bombai $\left(21.92 \mathrm{~m}^{3}\right)$. Langra had the highest percentage of perfect flower (27\%), while the lowest was in Deori and Kalia (5\%). The earliest and latest fruit was harvested from BARI Aam-1 and Ashwina, respectively, at all locations. All the cultivars were harvested 3-5 and 8-10 days earlier at Akbarpur and Gazipur, respectively, compared to that at Chapai Nawabgonj. The highest individual fruit weight was obtained from Fazli at all locations, while Gopalbhog (130 g) had the lowest fruit weight at Akbarpur and Surjapuri at Chapai Nawabgonj (172 g) and Gazipur (140 g). Total soluble solids content was reasonably high in all the cultivars at each location (around 20\%) except Ashwina, Lata Bombai, and Surjapuri which contained around $16 \%$ TSS. Lata Bombai was highly susceptible to anthracnose, floral malformation, and stem-end-rot at almost all the locations. Other cultivars showed low to medium susceptibility to all these diseases. The highest and lowest fruit producing cultivars were Khirsapat (206) and Lata Bombai (106) at Gazipur, while Rani Passand (196) and Bombai, Lata Bombai (92) at Akbarpur but at Chapai Nawabgonj, these were Langra (325) and Deori (117), respectively. Cultivar Fazli $(83.61 \mathrm{~kg}$ ) was the highest yielder by weight, while Lata Bombai $(18.35 \mathrm{~kg})$ was the lowest. Among the locations, Chapai Nawabgonj was the most favourable for plant growth, perfect flower production, and yield, and least favourable for pests and diseases. The overall result of the experiment indicated that good quality mango could also be grown successfully under Akbarpur and Gazipur conditions adopting appropriate variety like Khirsapat.
\end{abstract}

Kewords: Mango cultivars, agro-ecological zones of Bangladesh.

\section{Introduction}

In Bangladesh, mango ranks $2^{\text {nd }}$ in terms of area and $3^{\text {rd }}$ in terms of production. Bangladesh produces 898161 metric tons of mangoes annually from 31059 hectares

${ }^{1}$ Scientific Officer, Pomology Division, HRC, Bangladesh Agricultural Research Institute (BARI), Gazipur, ${ }^{2}$ Principal Scientific Officer, Pomology Division, HRC, BARI, Gazipur, ${ }^{3}$ Senior Scientific Officer, Pomology Division, HRC, BARI, Gazipur, ${ }^{3}$ Director, HRC, BARI, Gazipur, Bangladesh. 
of land (BBS, 2010). Mango is now recognized as one of the choicest fruits in the world and is called the "King of fruits". It is rich in several vitamins and minerals. The composition generally differs with cultivar and the stage of maturity. There is perhaps no fruit other than ripe mango that contains so much carotene and unripe mango occupies the first position among all major fruits in containing iron.

Mango grows well in all types of soil with suitable $\mathrm{pH}$ range from 5.5 to 7.0 (Whiley, 1984), but it can be grown commercially up to $\mathrm{pH} 8.5$ with proper nutritional management. It can grow well within the temperature ranging $24-30^{\circ} \mathrm{C}$ (Corbineau et al.,1986). Mangoes are grown in almost all parts of Bangladesh but commercial and good quality mangoes are mostly grown in the north-western and south-western districts of the country. Bangladesh is blessed with a good number of commercial and promising cultivars of mango. Now a days, some progressive farmers have come forward to establish commercial mango orchard in different parts of the country. But they do not know which variety can be suitable for commercial cultivation for that region. The performance of those cultivars at various locations has not been assessed so far. Result of such a trial would provide information about the comparative performance in respect of adaptability, yielding ability, and quality of mango. The study would be useful for the growers to identify the suitable cultivars for different agro-ecological zones of Bangladesh.

\section{Materials and Method}

The experiment was conducted at the Fruit Research Farm of three different stations of Bangladesh Agricultural Research Institute (BARI) viz., Akbarpur (AEZ 29), Chapai Nawabganj (AEZ 11), and Gazipur (AEZ 28) during August 2006 to July 2007. Three locations of the present experiment belong to sub-tropical climate

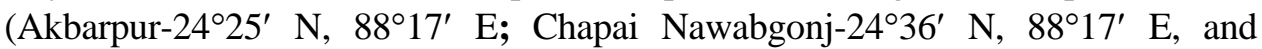
Gazipur- $24^{\circ} \mathrm{N}, 90^{\circ} 26^{\prime} \mathrm{E}$ ) characterized by moderate to heavy rainfall, high humidity, high temperature, short clear sunshine during the month from April to September and scanty rainfall, low humidity, low temperature, long clear sunshine and short day during the rest period of the year. In general, north-western region is drier than eastern side due to higher temperature and low rainfall and humidity. The soil of Akbarpur was strongly acidic with $4.1 \mathrm{pH}$. Organic matter content and fertility level are low. At Chapai Nawabgonj, the soils are fertile, well drained and slightly acidic to alkaline in nature with $\mathrm{pH}$ 6.0-8.1. The soil of Gazipur was occupied by heavy clay soil with acidic condition with pH 4.4-6.5 (BARC, 2005). Twelve commercial and promising cultivars of mango, namely Ashwina, Fazli, Gopalbhog, Khirshapat, Langra, BARI Aam-1, Bombai, Deori, Kalia, Lata Bombai, Rani Passand, and Surjapuri were included in the experiment. Each location had 36 mango plants, which were planted in July 1993 at a distance of $8 \mathrm{~m}$ $\times 8 \mathrm{~m}$. The experiment was laid out in Randomized Complete Block Design with three replications. A single tree of each cultivar constituted a unit plot. Fertilizer @ 
30 kg FYM, 1000 g urea, 500 g TSP, 350 g MoP, 350 g gypsum, and 15 g zinc sulphate were applied per plant in two splits in circular trench $(60 \mathrm{~cm}$ broad, $30 \mathrm{~cm}$ deep) $3 \mathrm{~m}$ away from the trunk. First split was applied at the end of September and second at the end of April. Weeding was done twice by ploughing following fertilizer application. Two full cover spray applications with Cypermethrin 10 EC @ $1 \mathrm{ml} / \mathrm{L}$ along with Tilt 250EC @ $0.5 \mathrm{ml} / \mathrm{L}$ first within 10 days of flowering when the flowers were not opened and the second after one month of first application were done. Irrigation, pruning, and disease and pest management were done as and when necessary. Tree volume was calculated using the formula of Castle (1983) with slight modifications.

$$
\text { Tree volume }\left(\mathrm{m}^{3}\right)=1 / 6 \pi \times \text { height } \times(2 \mathrm{r})^{2}
$$

Where, $2 \mathrm{r}=($ east-west spread + north-south spread $) / 2$

Leaf and panicle characteristics and diseases scoring were recorded using the Descriptors for Mango (IBPGR, 1989). The leaf area was estimated following the method of Saidha and Rao (1985).

$$
\text { Leaf area }\left(\mathrm{cm}^{2}\right) \mathrm{Y}=\mathrm{K} . \mathrm{X}
$$

Where $\mathrm{K}$ is constant (0.737) and $\mathrm{X}$ is length $\times$ breadth of leaf.

The recorded data on different parameters were statistically analyzed using MSTAT software. The difference between the treatment means was judged by Duncan’s New Multiple Range Test.

\section{Results and Discussion}

Wide variation was observed in respect of base girth (Table 1). At Akbarpur, the maximum base girth $(92.93 \mathrm{~cm})$ was recorded in Khirsapat followed by Bombai $(87.70 \mathrm{~cm})$ and Surjapuri $(87.62 \mathrm{~cm})$. The minimum of that was in Lata Bombai $(48.47 \mathrm{~cm})$. At Chapai Nawabgonj, it was maximum $(119.52 \mathrm{~cm})$ in Bombai followed by Fazli $(116.83 \mathrm{~cm})$ and Rani Passand $(114.33 \mathrm{~cm})$. The minimum $(68.67 \mathrm{~cm})$ was in Lata Bombai. At Gazipur, Surjapuri had the highest base girth $(94.62 \mathrm{~cm})$ and Lata Bombai had the lowest $(42.42 \mathrm{~cm})$. Regarding pooled value, Khirsapat had the highest base girth $(95.62 \mathrm{~cm})$ closely followed by Rani Passand $(95.25 \mathrm{~cm})$ and the lowest was in Lata Bombai $(53.18 \mathrm{~cm})$. Among the locations, the maximum base girth $(97.73 \mathrm{~cm})$ was recorded at Chapai Nawabgonj and the minimum was in Gazipur $(74.30 \mathrm{~cm})$. 
Table 1. Base girth and tree volume of twelve commercial and promising mango cultivars grown under different agro-climatic zones.

\begin{tabular}{l|c|c|c|c|c|c|c|c}
\hline \multirow{2}{*}{ Cultivar } & \multicolumn{7}{c}{ Base girth $(\mathrm{cm})$} & \multicolumn{3}{c}{ Tree volume $\left(\mathrm{cm}^{3}\right)$} \\
\cline { 2 - 8 } & Akbarpur & Chapai & Gazipur & $\begin{array}{c}\text { Pooled } \\
\text { value }\end{array}$ & Akbarpur & Chapai & Gazipur & Pooled value \\
\hline Ashwina & $52.13 \mathrm{~d}$ & $96.49 \mathrm{~cd}$ & $86.42 \mathrm{ab}$ & $78.35 \mathrm{de}$ & $54.81 \mathrm{bc}$ & $75.30 \mathrm{ab}$ & $59.80 \mathrm{~b}-\mathrm{e}$ & $63.30 \mathrm{c}$ \\
BARI Aam-1 & $71.72 \mathrm{bc}$ & $76.64 \mathrm{ef}$ & $68.23 \mathrm{~d}$ & $72.20 \mathrm{e}$ & $38.82 \mathrm{~d}$ & $51.33 \mathrm{c}$ & $42.56 \mathrm{f}$ & $44.24 \mathrm{e}$ \\
Bombai & $87.70 \mathrm{a}$ & $119.52 \mathrm{a}$ & $67.29 \mathrm{~d}$ & $91.50 \mathrm{ab}$ & $39.95 \mathrm{~d}$ & $50.50 \mathrm{c}$ & $46.10 \mathrm{ef}$ & $45.52 \mathrm{e}$ \\
Deori & $80.48 \mathrm{ab}$ & $83.60 \mathrm{de}$ & $52.55 \mathrm{e}$ & $72.21 \mathrm{e}$ & $56.42 \mathrm{bc}$ & $76.14 \mathrm{ab}$ & $60.60 \mathrm{~b}-\mathrm{e}$ & $64.39 \mathrm{c}$ \\
Fazli & $72.85 \mathrm{bc}$ & $116.83 \mathrm{a}$ & $79.13 \mathrm{bc}$ & $89.61 \mathrm{ab}$ & $55.73 \mathrm{bc}$ & $86.93 \mathrm{a}$ & $62.64 \mathrm{bcd}$ & $68.43 \mathrm{bc}$ \\
Gopalbhog & $85.45 \mathrm{ab}$ & $82.62 \mathrm{def}$ & $76.35 \mathrm{bcd}$ & $81.47 \mathrm{~cd}$ & $44.96 \mathrm{~cd}$ & $65.37 \mathrm{~b}$ & $50.36 \mathrm{def}$ & $53.56 \mathrm{~d}$ \\
Kalia & $60.11 \mathrm{~cd}$ & $99.33 \mathrm{bc}$ & $82.92 \mathrm{~b}$ & $80.79 \mathrm{~cd}$ & $65.40 \mathrm{ab}$ & $88.54 \mathrm{a}$ & $75.31 \mathrm{ab}$ & $76.42 \mathrm{a}$ \\
Khirshapat & $92.93 \mathrm{a}$ & $113.45 \mathrm{ab}$ & $80.47 \mathrm{bc}$ & $95.62 \mathrm{a}$ & $69.08 \mathrm{a}$ & $90.72 \mathrm{a}$ & $79.53 \mathrm{a}$ & $79.78 \mathrm{a}$ \\
Langra & $79.14 \mathrm{ab}$ & $107.3 \mathrm{abc}$ & $71.67 \mathrm{~cd}$ & $86.04 \mathrm{bc}$ & $50.39 \mathrm{~cd}$ & $77.39 \mathrm{ab}$ & $55.85 \mathrm{c}-\mathrm{f}$ & $61.21 \mathrm{c}$ \\
Lata Bombai & $48.47 \mathrm{~d}$ & $68.67 \mathrm{f}$ & $42.42 \mathrm{f}$ & $53.18 \mathrm{f}$ & $18.58 \mathrm{e}$ & $25.84 \mathrm{~d}$ & $21.33 \mathrm{~g}$ & $21.92 \mathrm{f}$ \\
Rani Passand & $84.94 \mathrm{ab}$ & $114.33 \mathrm{a}$ & $86.47 \mathrm{ab}$ & $95.25 \mathrm{a}$ & $55.82 \mathrm{bc}$ & $75.08 \mathrm{ab}$ & $62.96 \mathrm{bcd}$ & $64.62 \mathrm{c}$ \\
Surjapuri & $87.62 \mathrm{a}$ & $94.00 \mathrm{~cd}$ & $94.62 \mathrm{a}$ & $92.08 \mathrm{ab}$ & $63.46 \mathrm{ab}$ & $86.07 \mathrm{a}$ & $69.57 \mathrm{abc}$ & $73.04 \mathrm{ab}$ \\
\hline Mean & 75.30 & 97.73 & 74.05 & & 51.12 & 70.77 & 57.22 & 14.69 \\
CV (\%) & 9.99 & 8.13 & 7.97 & 8.72 & 13.46 & 11.68 & 13.20 \\
\hline
\end{tabular}

Note: Figures in a column followed by same letter(s) are not significantly different at 0.05 level of probability. 
At Akbarpur, the highest tree volume was found in Khirsapat $\left(69.08 \mathrm{~m}^{3}\right)$ closely followed by Kalia $\left(65.40 \mathrm{~m}^{3}\right)$ and Surjapuri $\left(63.46 \mathrm{~m}^{3}\right)$. The lowest of that was in Lata Bombai $\left(18.58 \mathrm{~m}^{3}\right)$. At Chapai Nawabgonj, Khirsapat had the maximum tree volume $\left(90.72 \mathrm{~m}^{3}\right)$ closely followed by Kalia $\left(88.54 \mathrm{~m}^{3}\right)$, Fazli $\left(86.93 \mathrm{~m}^{3}\right)$ and Surjapuri $\left(86.07 \mathrm{~m}^{3}\right)$. The minimum was in Lata Bombai $(25.84$ $\left.\mathrm{m}^{3}\right)$. At Gazipur, the highest tree volume was also observed in Khirsapat $\left(79.53 \mathrm{~m}^{3}\right)$ followed by Kalia $\left(75.31 \mathrm{~m}^{3}\right)$ and Surjapuri $\left(69.57 \mathrm{~m}^{3}\right)$. The lowest tree volume was in Lata Bombai $\left(21.33 \mathrm{~m}^{3}\right)$. Regarding pooled values, Khirsapat showed the highest tree volume $\left(79.78 \mathrm{~m}^{3}\right)$, while the lowest $\left(21.92 \mathrm{~m}^{3}\right)$ of that was in Lata Bombai. Among the locations, Chapai Nawabgonj showed the best result $\left(70.77 \mathrm{~m}^{3}\right)$ in respect of tree volume, while Akbarpur (51.12 $\mathrm{m}^{3}$ ) was the worst in this respect. This may be due to prevailing favourable climatic and soil conditions at Chapai Nawabgonj.

The leaves of Fazli were oblong lanceolate in shape, whereas Gopalbhog and Khirsapat had the elliptic lanceolate leaves. The leaves of the remaining cultivars were lanceolate in shape. The present study was in line with the findings of Bhuyan et al. (2003) who reported that leaf shape of Fazli was oblong laceolate, while it was elliptic lanceolate in Gopalbhog and Khirsapat, lanceolate in Ashwina, BARI Aam-1, Bombai, Kalia, Langra, Lata Bombai, Rani Passand, and Surjapuri but disagreed with Hossain et al. (2002) where the leaf shape of Ashwina and Fazli was oval lanceolate, while Khirsapat, Lata Bombai was ovate lanceolate. This variability might be due to the intra-varietal genetic variation. The leaf margins of BARI Aam-1, Langra, and Rani Passand were flat. The rest of the cultivars had wavy leaf margin. The leaf tip of Fazli was obtuse, whereas Kalia, Langra, and Surjapuri had the acuminate. The leaf tip of the remaining cultivars was acute. Bhuyan et al. (2003) confirmed this study but differ with the findings of Hossain et al. (2002) where the leaf tip of Ashwina and Fazli was acute, while Khirsapat and Lata Bombai was sub-acuminate. The colour of new leaf was light green in Bombai, Deori, Kalia, Khirsapat, Lata Bombai, and Surjapuri, while the remaining cultivars had reddish brown young leaf.

Significant variation was noted for leaf area in all the locations. At Akbarpur, highest leaf area $\left(125.30 \mathrm{~cm}^{2}\right)$ was recorded in Fazli followed by that in Langra $\left(97.59 \mathrm{~cm}^{2}\right)$ and the lowest was in Lata Bombai $\left(53.70 \mathrm{~cm}^{2}\right)$. At Chapai Nawabgonj, it was maximum $\left(200.60 \mathrm{~cm}^{2}\right)$ in Fazli followed by that of Khirsapat $\left(106.30 \mathrm{~cm}^{2}\right)$ and the minimum $\left(57.22 \mathrm{~cm}^{2}\right)$ was in Lata Bombai. At Gazipur, Fazli had the highest leaf area $\left(134.30 \mathrm{~cm}^{2}\right)$ and Lata Bombai had the lowest $\left(55.43 \mathrm{~cm}^{2}\right)$. In case of pooled value, Fazli showed the highest $\left(153.40 \mathrm{~cm}^{2}\right)$ leaf area and the lowest was in Lata Bombai $\left(55.45 \mathrm{~cm}^{2}\right)$, Among the locations, the maximum leaf area was recorded at Chapai Nawabgonj $\left(97.13 \mathrm{~cm}^{2}\right)$ while the minimum (76.59 $\mathrm{cm}^{2}$ ) was at Akbarpur. Bhuyan and Islam (1989) also confirmed the present findings where Fazli had the highest leaf area (199.89 $\mathrm{cm}^{2}$ ). Hossain et al. (2002) noted similar leaf area for Ashwina, Fazli, Khirsapat and Lata Bombai. 
Table 2. Leaf characteristics of twelve commercial and promising mango cultivars.

\begin{tabular}{|c|c|c|c|c|c|c|c|c|}
\hline \multirow{2}{*}{ Cultivar } & \multirow{2}{*}{ Leaf Shape } & \multirow{2}{*}{$\begin{array}{c}\text { Leaf } \\
\text { margin }\end{array}$} & \multirow{2}{*}{ Leaf tip } & \multirow{2}{*}{\begin{tabular}{|c|}
$\begin{array}{c}\text { Colour } \\
\text { of young } \\
\text { leaf }\end{array}$ \\
\end{tabular}} & \multicolumn{4}{|c|}{ Leaf area $\left(\mathrm{cm}^{2}\right)$} \\
\hline & & & & & Akbarpur & Chapai & Gazipur & Pooled value \\
\hline Ashwina & Lanceolate & Wavy & Acute & $\mathrm{RB}$ & 63.48cde & 75.15 e & 78.12 bc & 72.25 ef \\
\hline BARI Aam-1 & Lanceolate & Flat & Acute & $\mathrm{RB}$ & $78.51 \mathrm{bcd}$ & $102.30 \mathrm{bc}$ & $86.50 \mathrm{~b}$ & 89.12 bc \\
\hline Bombai & Lanceolate & Wavy & Acute & LG & 83.15 bc & 89.37 b-e & 86.91 b & 86.48bcd \\
\hline Deori & Lanceolate & Wavy & Acute & LG & 68.68cde & 96.37bcd & 66.33 bc & 77.12 def \\
\hline Fazli & OL & Wavy & Obtuse & $\mathrm{RB}$ & $125.30 \mathrm{a}$ & $200.60 \mathrm{a}$ & $134.30 \mathrm{a}$ & $153.40 \mathrm{a}$ \\
\hline Gopalbhog & EL & Wavy & Acute & $\mathrm{RB}$ & 73.93cde & 91.93 b-e & 75.65 bc & 80.50cde \\
\hline Kalia & Lanceolate & Wavy & Acuminate & LG & 69.62cde & 81.47 de & 72.49 bc & 74.53 ef \\
\hline Khirshpat & EL & Wavy & Acute & LG & 72.65cde & $106.30 \mathrm{~b}$ & 79.15 bc & 86.02bcd \\
\hline Langra & Lanceolate & Flat & Acuminate & $\mathrm{RB}$ & $97.59 \mathrm{~b}$ & $101.30 \mathrm{bc}$ & 82.64 b & 93.84 b \\
\hline Lata Bombai & Lanceolate & Wavy & Acute & LG & $53.70 \mathrm{e}$ & $57.22 \mathrm{f}$ & $55.43 \mathrm{c}$ & $55.45 \mathrm{~g}$ \\
\hline Rani Passand & Lanceolate & Flat & Acute & $\mathrm{RB}$ & 75.04cde & 85.91cde & 84.06 b & 81.67cde \\
\hline Surjapuri & Lanceolate & Wavy & Acuminate & LG & $57.41 \mathrm{de}$ & 77.64 de & $67.67 \mathrm{bc}$ & $67.58 \mathrm{f}$ \\
\hline Mean & - & - & - & - & 76.59 & 97.13 & 80.77 & - \\
\hline CV (\%) & - & - & - & - & 15.80 & 10.67 & 16.11 & 14.00 \\
\hline
\end{tabular}

Note: Figures in a column followed by same letter(s) are not significantly different at 0.05 level of probability.

$\mathrm{OL}=$ Oblong lanceolate, $\mathrm{EL}=$ Elliptic lanceolate, $\mathrm{RB}=$ Reddish brown, $\mathrm{LG}=$ Light green 
Fazli, Kalia, Langra, and Rani Passand had pyramidal shape and the rest of the cultivars had conical shaped inflorescence (Table 3). The inflorescence position of Bombai, Fazli, Kalia, Langra, and Rani Passand was both terminal and axillary and that of the remaining cultivars was terminal. The panicle colour of Bombai, Deori, Kalia, and Rani Passand was light green, while that of the rest cultivars was green with red patches. All of the studied cultivars had pentamerous flowers containing 5 sepals and 5 petals except BARI Aam- 1 and Fazli in which flowers were both tetramerous and pentamerous containing 4-5 sepals and 4-5 petals. Flower types of the studied mango cultivars were in line with the findings of Bhuyan et al. (2003).

Inflorescence length ranged from $26.73 \mathrm{~cm}$ in Rani Passand to $32.77 \mathrm{~cm}$ in Surjapuri at Akbarpur and at Chapai Nawabgonj, it varied from $24.60 \mathrm{~cm}$ in Langra to $35.37 \mathrm{~cm}$ in Surjapuri. A significant variation was observed in inflorescence length among the cultivars at Gazipur where Deori had the maximal $(39.47 \mathrm{~cm})$ and Lata Bombai $(18.91 \mathrm{~cm})$ had the minimal inflorescence length. For pooled values, Surjapuri exhibited the highest inflorescence length (35.06 $\mathrm{cm}$ ) while the lowest was in Langra $(25.07 \mathrm{~cm})$. Among the locations, Akbarpur showed maximum $(29.78 \mathrm{~cm})$, while Chapai Nawabgonj showed minimum $(29.25 \mathrm{~cm})$ inflorescence length. The present study is dissimilar with the result of Haque et al. (1993) who reported that the inflorescence length of Gopalbhog, Langra, Lata Bombai and Fazli was 32.3, 37.3, 33.0, and $28.6 \mathrm{~cm}$, respectively. Bhuyan and Islam (1989) also observed 29.04, 27.08, 25.33, 31.67, and $31.67 \mathrm{~cm}$ long inflorescence in Langra, Fazli, Gopalbhog, Khirsapat, and Ashwina, respectively. This variability might be due to genetic variation among the cultivars as well as strong influence of environment and cultural factors.

The variation of percent male flower among the cultivars was statistically similar except Langra, which was significantly lower than that of other cultivars at all locations (Fig. 1-4). At Akbarpur, the highest percentage of male flower (90\%) was recorded in Surjapuri, while it was highest in Kalia and Khirsapat (90\%) at Chapai Nawabgonj and in Gopalbhog (91\%) at Gazipur. Langra had the lowest percentage of male flower at Akbarpur (62\%), Chapai Nawabgonj (62\%), and Gazipur (64\%). Considering pooled values, Kalia had the maximum (90\%), and Langra had the minimum (63\%) male flower. Among the locations, Gazipur had the maximum percentage of male flower. From a keen observation, Mukherjee (1997) concluded that the ratio of male to perfect flowers was strongly influenced by environmental and cultural factors.

Significant variations were found in the percentage of perfect flower among the cultivars at all locations. At Akbarpur (27\%), Chapai Nawabgonj (29\%), and Gazipur (25\%), Langra had the maximum perfect flower. The minimum percentage was found in Deori, Gopalbhog, and Kalia (5\%) at Akbarpur, Gopalbhog and Kalia (6\%) at Chapai Nawabgonj, Deori and Kalia (5\%) at Gazipur. Variation was also found in pooled values. Langra had the highest percentage of perfect flower (27\%), while the lowest was in Deori and Kalia (5\%). Considering locations, Chapai Nawabgonj produced the maximum percentage of perfect flower. 
Table 3. Inflorescence characteristics of twelve commercial and promising mango cultivars.

\begin{tabular}{|c|c|c|c|c|c|c|c|c|}
\hline \multirow[t]{2}{*}{ Cultivar } & \multirow[t]{2}{*}{ Shape } & \multirow[t]{2}{*}{ Position } & \multirow[t]{2}{*}{ Colour } & \multirow[t]{2}{*}{ Type of flower } & \multicolumn{4}{|c|}{ Inflorescence length $(\mathrm{cm})$} \\
\hline & & & & & Akbarpur & Chapai & Gazipur & Pooled value \\
\hline Ashwina & Conical & Terminal & GRP & Pentamerous & 32.27 & 31.27 & $29.73 \mathrm{ab}$ & 31.09 abc \\
\hline BARI Aam-1 & Conical & Terminal & GRP & ВTP & 30.20 & 31.60 & 27.57 abc & 29.79 b-e \\
\hline Bombai & Conical & TA & LG & Pentamerous & 27.43 & 28.13 & 29.84 abc & 28.47 b-e \\
\hline Deori & Conical & Terminal & LG & Pentamerous & 30.23 & 27.87 & 39.47 a & $32.52 \mathrm{ab}$ \\
\hline Fazli & Pyramidal & TA & GRP & BTP & 32.77 & 31.87 & 29.17 abc & 31.27 abc \\
\hline Gopalbhog & Conical & Terminal & GRP & Pentamerous & 29.08 & 27.40 & $35.43 \mathrm{ab}$ & $30.64 \mathrm{a}-\mathrm{d}$ \\
\hline Kalia & Pyramidal & TA & LG & Pentamerous & 29.17 & 28.21 & $29.40 \mathrm{abc}$ & 28.93 b-e \\
\hline Khirshpat & Conical & Terminal & GRP & Pentamerous & 27.93 & 29.77 & $29.20 \mathrm{abc}$ & 28.97 b-e \\
\hline Langra & Pyramidal & TA & GRP & Pentamerous & 28.30 & 24.60 & $22.30 \mathrm{bc}$ & $25.07 \mathrm{e}$ \\
\hline Lata Bombai & Conical & Terminal & GRP & Pentamerous & 30.45 & 27.86 & 18.91 c & 25.74 de \\
\hline Rani Passand & Pyramidal & TA & LG & Pentamerous & 26.73 & 27.10 & $26.43 \mathrm{abc}$ & 26.76 cde \\
\hline Surjapuri & Conical & Terminal & GRP & Pentamerous & 32.77 & 35.37 & 37.03ab & $35.06 \mathrm{a}$ \\
\hline Mean & - & - & - & - & 29.78 & 29.25 & 29.54 & - \\
\hline CV (\%) & - & - & - & - & 14.27 & 14.63 & 18.67 & 15.98 \\
\hline
\end{tabular}

Note: Figures in a column followed by same letter(s) are not significantly different at 0.05 level of probability.

TA $=$ Terminal \& axillary, GRP $=$ Green with red patches, $\mathrm{LG}=$ Light green, $\mathrm{BTP}=$ both tetramerous \& pentamerous 


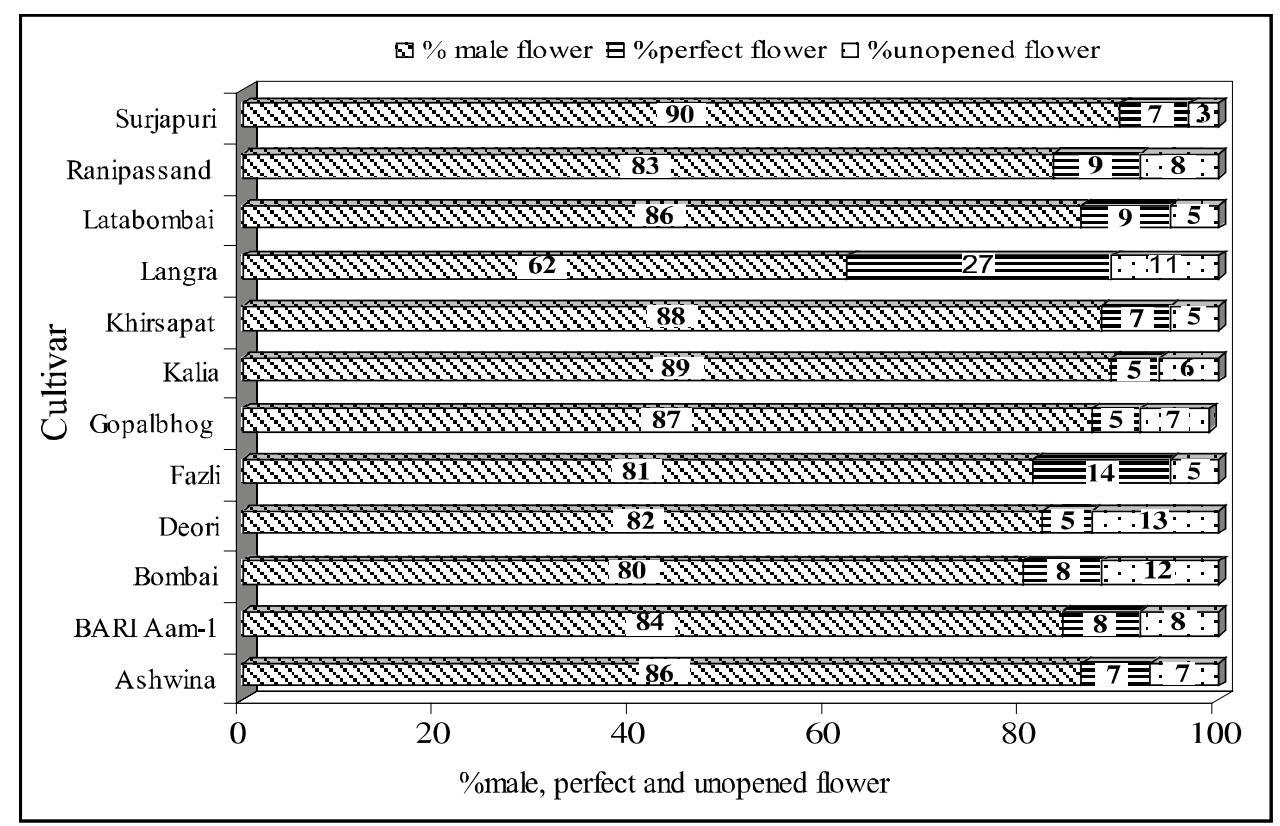

Fig. 1. Percentage of male, perfect and unopened flowers of twelve commercial and promising mango cultivars grown at Akbarpur.

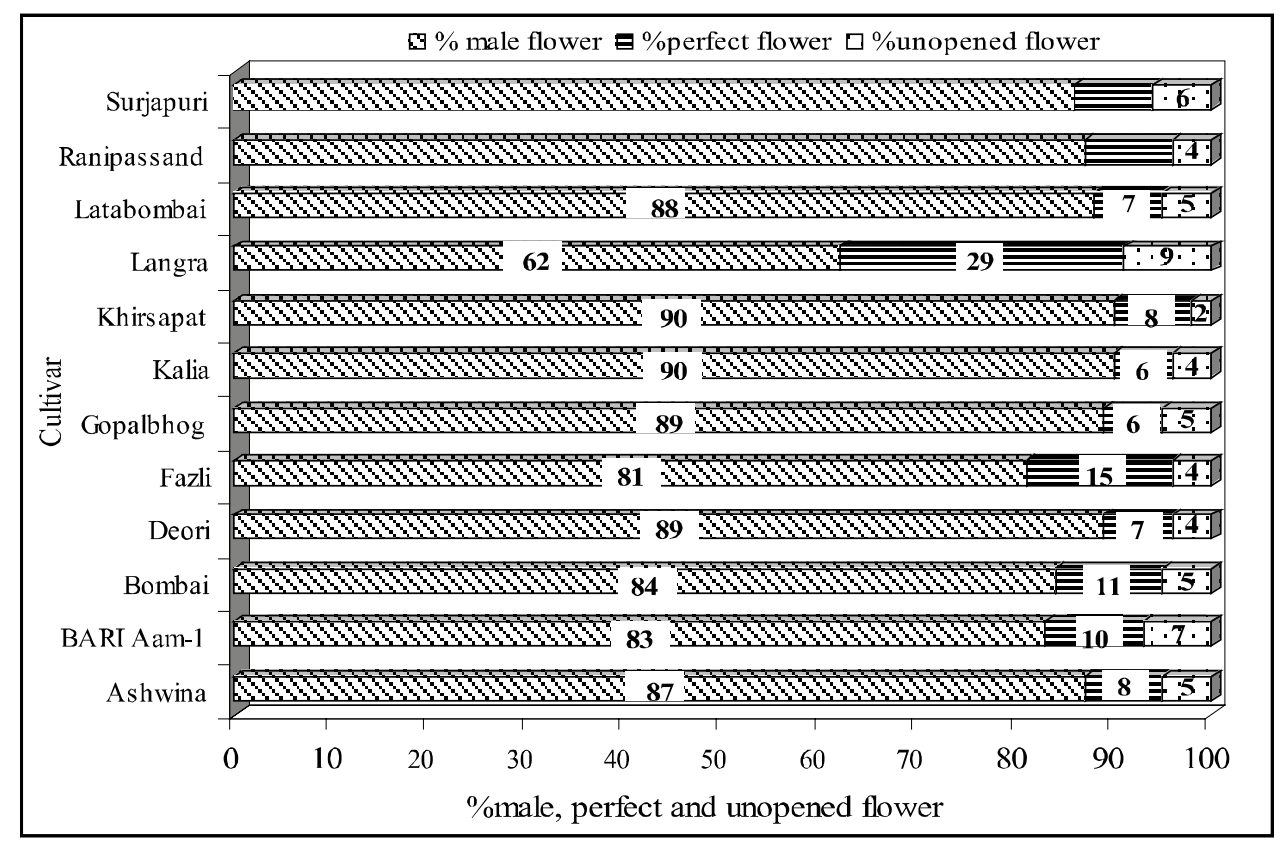

Fig. 2. Percentage of male, perfect and unopened flowers of twelve commercial and promising mango cultivars grown at Chapai Nawabgonj. 


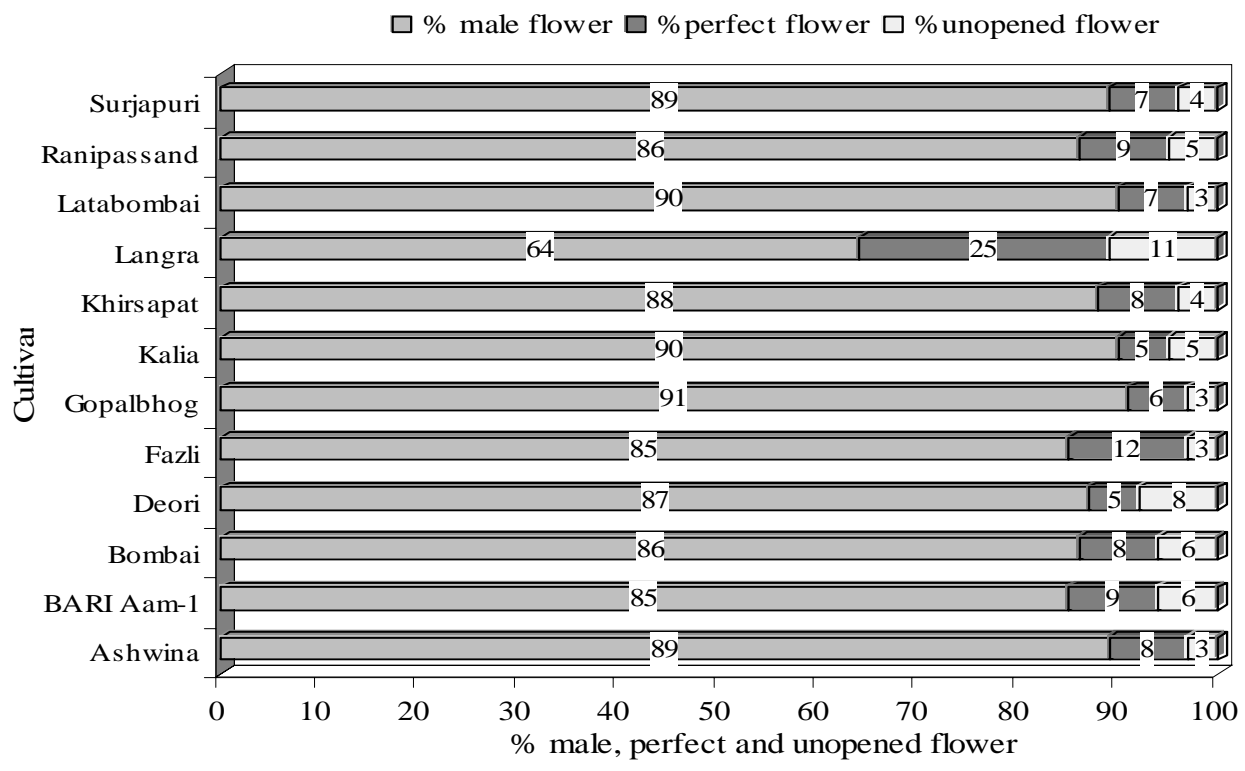

Fig. 3. Percentage of male, perfect and unopened flowers of twelve commercial and promising mango cultivars grown at Gazipur.

At Akbarpur, Deori produced the highest (13\%) unopened flower. It was lowest in Surjapuri (3\%). The maximum unopened flower (9\%) was recorded in Langra at Chapai Nawabgonj and the lowest was in Khirsapat (2\%). Gazipur also showed the maximum percentage of unopened flower in Langra (11\%), while minimal in Ashwina, Fazli, Gopalbhog and Lata Bombai (3\%). Regarding pooled values, the highest unopened flower was in Langra (10\%) and the lowest in Fazli, Khirsapat, Lata Bombai and Surjapuri (4\%). Among the locations, Akbarpur showed the highest unopened flower.

Full bloom of the cultivars took place between 18 February and 05 March at Akbarpur (Table 4). Kalia was the earliest and Lata Bombai was the latest in respect of full bloom. At Chapai Nawabgonj, full bloom took place from 20 February to 8 March where Ashwina and Kalia were earliest and Rani Passand was the latest. In case of Gazipur, earliest full bloom was observed in Kalia (15 February) and the latest in Langra (2 March). The variability found in the present study is in agreement with the findings of Valmayor (1962) who reported that the variation of blooming period is dependent upon the combination of environmental factors and the condition of plant. Majumder and Sharma (1985) stated that unlike many other fruits, flowering in mango is entirely dependent on climatic conditions prevailing in an area. It is reported that for each 400 feet increase in altitude, flowering is retarded by four days and similarly for each degree of latitude towards south and north of the tropics, flowering is advanced and delayed by four days, respectively. 


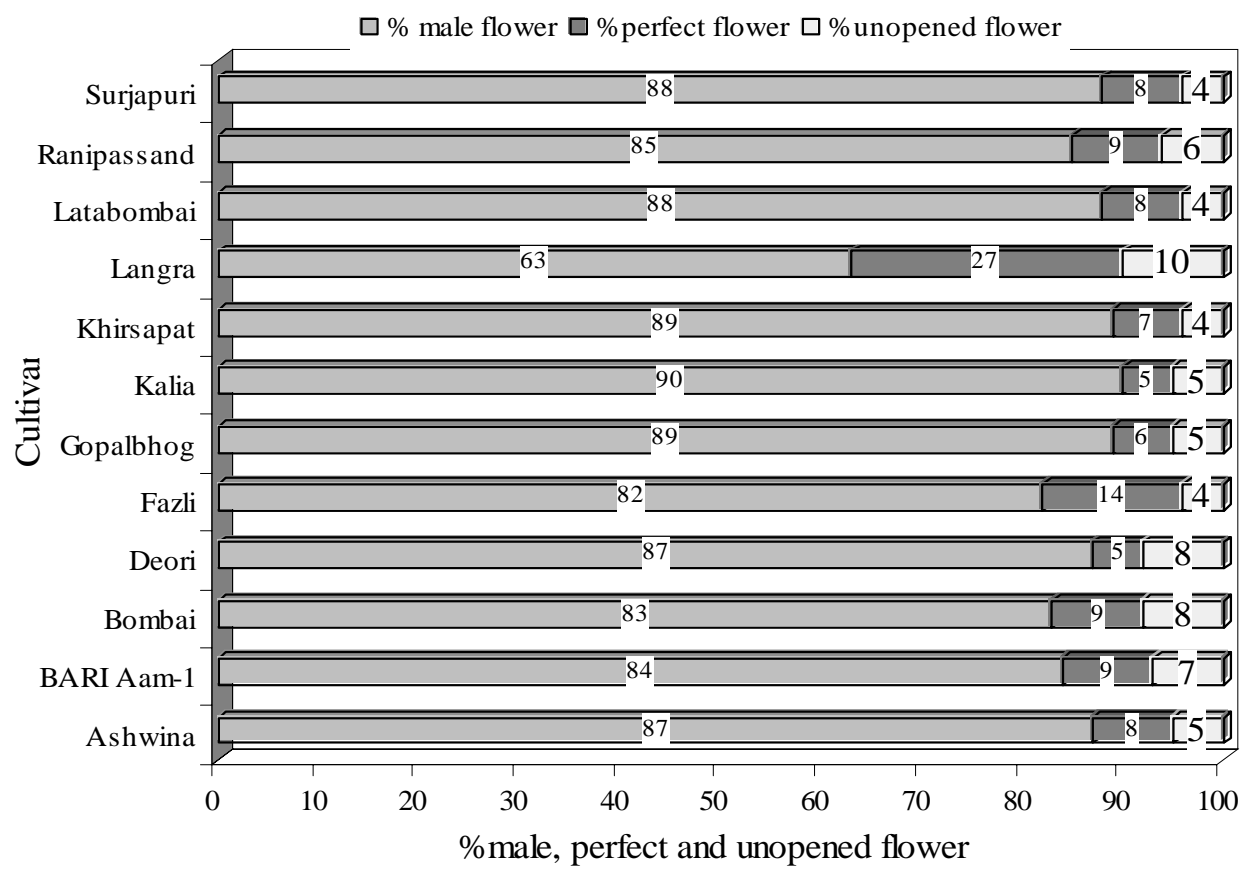

Fig. 4. Pooled values of male, perfect and unopened flower percentages of twelve commercial and promising mango cultivars grown under different agro-climatic zones.

The fruits of all the cultivars at Akbarpur were harvested between 03 June and 15 July 2007 (Table 4). BARI Aam- 1 was the earliest (03 June) followed by Gopalbhog (05 June), while Ashwina was the latest (15 July) preceded by Fazli (08 July), respectively. At Chapai Nawabgonj, the early harvested fruits were obtained from BARI Aam-1 and Gopalbhog (05 June) and the latest from Ashwina (18 July) preceded by Fazli (12 July). At Gazipur, BARI Aam-1 and Deori were the early harvested cultivars (30 May) followed by Kalia (02 June), while Ashwina was the latest (10 July) preceded by Fazli (02 July). The results are in agreement with the findings of Bhuyan and Islam (1989). Haque et al. (1993) reported that the fruits of Gopalbhog, Langra, Lata Bombai, Bombai, and Fazli were harvested on 26 May, 8 June, 27 June, 8 June, and 29 June, respectively, under the climatic condition of Jessore. This variation might be due to the locations enjoying different environmental conditions, management practices, and year of production. Bhuyan and Islam (1989) recorded the harvesting time of Gopalbhog, Khirsapat, Langra, Fazli and Ashwina as 31 May, 2 June, 17 June, 10 July, and 21 July, respectively, under the climatic condition of Chapai Nawabgonj. Valmayor (1962) stated that harvesting time of mango may vary depending on the time of flowering and climatic factors during the growing season. 
Table 4. Blooming and harvesting period of twelve commercial and promising mango cultivars grown under different agro-climatic zones.

\begin{tabular}{|c|c|c|c|c|c|c|}
\hline \multirow{2}{*}{ Cultivars } & \multicolumn{3}{|c|}{ Date of full bloom } & \multicolumn{3}{|c|}{ Date of harvest } \\
\hline & Akbarpur & Chapai & Gazipur & Akbarpur & Chapai & Gazipur \\
\hline Ashwina & 20 Feb’07 & 20 Feb’07 & 18 Feb’07 & 15 July’07 & 18 July’07 & 10 July’07 \\
\hline BARI Aam-1 & 24 Feb’07 & 25 Feb’07 & 20 Feb’07 & 03 June’07 & 05 June’07 & 30 May’07 \\
\hline Bombai & 3 Mar ’07 & 5 Mar’07 & 28 Feb’07 & 23 June’07 & 25 June’07 & 20 June’07 \\
\hline Deori & 22 Feb’07 & 25 Feb’07 & 19 Feb’07 & 07 June’07 & 10 June’07 & 30 May’07 \\
\hline Fazli & 4 Mar’07 & 6 Mar’07 & 1 Mar’07 & 08 July’07 & 12 July’07 & 02 Jul’07 \\
\hline Gopalbhog & 26 Feb’07 & 28 Feb’07 & 24 Feb’07 & 05 June’07 & 05 June’07 & 03 June’07 \\
\hline Kalia & 18 Feb’07 & 20 Feb’07 & 15 Feb’07 & 06 June’07 & 08 June’07 & 02 Jun’07 \\
\hline Khirsapat & 26 Feb’07 & 28 Feb’07 & 23 Feb’07 & 11 June’07 & 12 June’07 & 07 Jun’07 \\
\hline Langra & 4 Mar’07 & 6 Mar’07 & 2 Mar’07 & 17 June’07 & 18 June’07 & 15 Jun’07 \\
\hline Lata Bombai & 5 Mar’07 & 7 Mar’07 & 1 Mar’07 & 23 June’07 & 25 June’07 & 20 Jun’07 \\
\hline Rani Passand & 3 Mar’07 & 8 Mar’07 & 28 Feb’07 & 12 June’07 & 12 June’07 & 08 Jun’07 \\
\hline Surjapuri & 22 Feb’07 & 27 Feb’07 & 18 Feb’07 & 20 June’07 & 22 June’07 & 18 June’07 \\
\hline
\end{tabular}


The heaviest fruit was obtained from Fazli (503 g) followed by Ashwina (388 g) and the lightest from Gopalbhog (130 g) at Akbarpur (Table 5). At Chapai Nawabgonj, the highest individual fruit weight was recorded in Fazli (648 g) followed by that of Ashwina (424 g). The lowest was in Surjapuri (172 g). Maximum individual fruit weight was produced by Fazli (536 g) at Gazipur and the minimum by Surjapuri (140 g). For pooled values, highest individual fruit weight was obtained from Fazli (562 g) and the lowest (162 g) from Rani Passand. Regarding this character, Chapai Nawabgonj gave the best result among the locations. The results were in consonance with those of Bhuyan and Islam (1989) but differ with the findings of Haque et al. (1993) under the climatic condition of Jessore. This variation might be due to environmental conditions and management practices. Even genetic differences between trees with the same name are possible.

Total soluble solids (TSS) content ranged from $16.7 \%$ in Lata Bombai to 22.5\% in Gopalbhog at Akbarpur. At Chapai Nawabgonj, Rani Passand had the highest TSS (24.5 \%). The lowest TSS was in Lata Bombai (17.7\%). Under Gazipur condition, Gopalbhog had the highest (21.6\%) and Lata Bombai had the lowest $(16.8 \%)$ TSS. In case of pooled value, Gopalbhog gave the maximum (22.5\%) and Lata Bombai gave the minimum (17.1\%) TSS. Among the locations, the highest total soluble solid content (21.4\%) was recorded at Chapai Nawabgonj. The present finding conformed to the result of Bhuyan and Islam (1989) where Gopalbhog had the highest (22.63 \%) and Fazli had the lowest TSS (17.47\%).

Lata Bombai was highly susceptible to anthracnose, while Ashwina and Fazli were moderately susceptible at Akbarpur. The rest of the cultivars were less susceptible to this disease. At Chapai Nawabgonj, Ashwina, Fazli, and Lata Bombai were moderately susceptible. Remaining cultivars were less susceptible to this disease (Table 6). Under Gazipur condition, Lata Bombai was also found highly susceptible, while Ashwina, Fazli, Gopalbhog and Khirsapat were medium susceptible to anthracnose. The rest of the cultivars were less susceptible. The present results are in accord with that of Bhuyan et al. (2003).

The results revealed that all the cultivars were less susceptible to floral malformation except Lata Bombai which was highly susceptible at Akbarpur. At Chapai Nawabgonj, Lata Bombai was highly susceptible, whereas Bombai and Khirsapat were moderately susceptible. Lata Bombai also showed the highest susceptibility to floral malformation at Gazipur. The remaining cultivars were less susceptible.

At Akbarpur, Lata Bombai exhibited the highest susceptibility while Ashwina, Fazli, Gopalbhog, and Khirsapat were medium susceptible to stem-endrot. Other cultivars were less susceptible. Ashwina and Fazli were moderately susceptible and the remaining cultivars were less susceptible at Chapai 
Nawabgonj. At Gazipur, Lata Bombai also showed the highest susceptibility, while Ashwina, Fazli, Gopalbhog, and Khirsapat were moderately susceptible to this disease. The rest of the cultivars were less susceptible. The present finding is in line with the results of Bhuyan et al. (2003).

At Akbarpur, Bombai, Fazli, Gopalbhog, Khirsapat, Langra and Lata Bombai were medium susceptible to stem borer. The remaining cultivars were less susceptible. While at Chapai Nawabgonj, all the studied cultivars were found to be less susceptible to stem borer. At Gazipur, Bombai, Fazli, Khirsapat, Gopalbhog, Langra, and Lata Bombai were found to be medium susceptible and the remaining cultivars were less susceptible to that insect pest. Anonymous (2004) reported that at Joybebpur and in the surrounding, stem borer was found to be very serious. The results of Akbarpur revealed that the moderate infestation of fruit fly was found in Khirsapat, Langra, and Lata bombai, while minimum infestation was found in rest of the cultivars. Under Chapai Nawabgonj condition, the variety Khirsapat was found to be maximum infested by fruit fly, while Ashwina, BARI Aam-1, Bombai, Fazli, Kalia, Rani Passand, and Surjapuri were minimum and the remaining cultivars were medium susceptible. At Gazipur, Khirsapat, Langra, and Lata Bombai showed medium susceptibility and the rest of the cultivars were less susceptible. Bhuyan et al. (2003) reported that fruits of Khirsapat, Langra, and Ashwina were medium susceptible to fruit fly infestation.

At Akbarpur and Gazipur, all the cultivars under study were less susceptible to fruit weevil but at Chapai Nawabgonj, it was absent in all the cultivars. According to Karim and Ahmed (1989), the mango fruit weevil (Sternochetus frigidus) is the most destructive pest of mango fruits of trees grown from seeds in all districts on the eastern side of the Jamuna River in Bangladesh. It is observed that grafted trees are less susceptible to fruit weevil than the seedling trees of mango.

A great variation was observed in number of fruits per plant among the cultivars studied (Table 8). Khirsapat produced the maximal number of fruits per plant (206) at Akbarpur, while Lata Bombai had the minimal (106). At Chapai Nawabgonj, the highest number of fruits per plant was produced by Langra (325) and the lowest by Deori (117). At Gazipur, the maximum number of fruits per plant was produced by Rani Passand (196) closely followed by that of Khirsapat (190) and the minimal by Lata Bombai and Bombai (92). Considering pooled values, Langra produced the maximum number of fruits per plant (211) closely followed by Khirsapat (206) and the lowest by Lata Bombai (111). Among the locations, Chapai Nawabgonj performed the best.

Wide variations among the cultivars in respect of yield per plant were recorded at all the locations. At Akbarpur, maximum yield was obtained from Fazli $(64.70 \mathrm{~kg}$ ) closely followed by that of Ashwina $(64.20 \mathrm{~kg})$, while the minimum from Lata Bombai (16.66 kg). At Chapai Nawabgonj, highest yield $(129.88 \mathrm{~kg})$ was also produced by Fazli and the lowest yield $(24.85 \mathrm{~kg})$ was 
found in Lata Bombai. At Gazipur, Fazli gave the highest yield (56.25 kg) whereas Lata Bombai had the lowest yield (13.54 kg). A significant variation was also observed for pooled values where Fazli had the maximum yield (83.61 kg) and Lata Bombai had the minimum (18.35 kg). Among the locations, Chapai Nawabgonj was the best in this respect. Majumder et al. (2001) reported that the yield is a highly variable factor depending upon the cultivars and age of the plants, climatic conditions, incidence of the pests and diseases, etc.

It may be inferred from the overall results of the experiment that almost all the cultivars showed better performance in respect of tree growth, yield, fruit quality and pest and disease incidence under Chapai Nawabgonj condition. Only Khirsapat exhibited static performance over locations. Good quality mango can also be grown successfully under Akbarpur and Gazipur conditions adopting appropriate variety like Khirsapat. 
Table 5. Individual fruit weight and TSS content of twelve commercial and promising mango cultivars grown under different agro-climatic zones.

\begin{tabular}{l|c|c|c|c|c|c|c|c}
\hline \multirow{2}{*}{ Cultivar } & \multicolumn{3}{c}{ Individual fruit weight (g) } & \multicolumn{4}{c}{ TSS (\%) } \\
\cline { 2 - 9 } & Akbarpur & Chapai & Gazipur & $\begin{array}{c}\text { Pooled } \\
\text { value }\end{array}$ & Akbarpur & Chapai & Gazipur & $\begin{array}{c}\text { Pooled } \\
\text { value }\end{array}$ \\
\hline Ashwina & $388 \mathrm{~b}$ & $424 \mathrm{~b}$ & $314 \mathrm{~b}$ & $375 \mathrm{~b}$ & $17.9 \mathrm{~cd}$ & $18.7 \mathrm{de}$ & $17.3 \mathrm{de}$ & $18.0 \mathrm{~d}$ \\
BARI Aam-1 & $162 \mathrm{ef}$ & $202 \mathrm{ef}$ & $151 \mathrm{e}$ & $172 \mathrm{fg}$ & $20.0 \mathrm{bc}$ & $20.5 \mathrm{~cd}$ & $19.8 \mathrm{abc}$ & $20.1 \mathrm{c}$ \\
Bombai & $266 \mathrm{~cd}$ & $363 \mathrm{c}$ & $302 \mathrm{~b}$ & $310 \mathrm{c}$ & $20.0 \mathrm{bc}$ & $23.2 \mathrm{ab}$ & $20.7 \mathrm{ab}$ & $21.3 \mathrm{~b}$ \\
Deori & $290 \mathrm{c}$ & $256 \mathrm{~d}$ & $273 \mathrm{bc}$ & $273 \mathrm{~d}$ & $20.6 \mathrm{ab}$ & $22.2 \mathrm{abc}$ & $21.0 \mathrm{ab}$ & $21.2 \mathrm{~b}$ \\
Fazli & $503 \mathrm{a}$ & $648 \mathrm{a}$ & $536 \mathrm{a}$ & $562 \mathrm{a}$ & $19.8 \mathrm{bc}$ & $20.4 \mathrm{~cd}$ & $19.1 \mathrm{bcd}$ & $19.8 \mathrm{c}$ \\
Gopalbhog & $130 \mathrm{f}$ & $210 \mathrm{def}$ & $239 \mathrm{~cd}$ & $193 \mathrm{f}$ & $22.5 \mathrm{a}$ & $23.6 \mathrm{ab}$ & $21.6 \mathrm{a}$ & $22.5 \mathrm{a}$ \\
Kalia & $234 \mathrm{~d}$ & $251 \mathrm{de}$ & $215 \mathrm{~d}$ & $233 \mathrm{e}$ & $21.7 \mathrm{ab}$ & $21.3 \mathrm{bc}$ & $21.4 \mathrm{a}$ & $21.5 \mathrm{ab}$ \\
Khirshapat & $230 \mathrm{~d}$ & $260 \mathrm{~d}$ & $229 \mathrm{~cd}$ & $240 \mathrm{e}$ & $21.6 \mathrm{ab}$ & $22.8 \mathrm{ab}$ & $20.5 \mathrm{ab}$ & $21.6 \mathrm{ab}$ \\
Langra & $243 \mathrm{~d}$ & $244 \mathrm{de}$ & $238 \mathrm{~cd}$ & $242 \mathrm{e}$ & $21.5 \mathrm{ab}$ & $23.3 \mathrm{ab}$ & $21.5 \mathrm{a}$ & $22.1 \mathrm{ab}$ \\
Lata Bombai & $157 \mathrm{ef}$ & $185 \mathrm{f}$ & $147 \mathrm{e}$ & $163 \mathrm{~g}$ & $16.7 \mathrm{~d}$ & $17.7 \mathrm{e}$ & $16.8 \mathrm{e}$ & $17.1 \mathrm{~d}$ \\
Rani Passand & $158 \mathrm{ef}$ & $179 \mathrm{f}$ & $149 \mathrm{e}$ & $162 \mathrm{~g}$ & $20.2 \mathrm{~b}$ & $24.5 \mathrm{a}$ & $21.0 \mathrm{ab}$ & $21.9 \mathrm{ab}$ \\
Surjapuri & $181 \mathrm{e}$ & $172 \mathrm{f}$ & $140 \mathrm{e}$ & $164 \mathrm{~g}$ & $16.7 \mathrm{~d}$ & $18.7 \mathrm{de}$ & $18.0 \mathrm{cde}$ & $17.8 \mathrm{~d}$ \\
\hline Mean & 245.2 & 282.8 & 244.3 & - & 19.95 & 21.40 & 19.89 & 5.41 \\
CV (\%) & 8.66 & 9.90 & 10.38 & 9.72 & 5.94 & 5.88 & 5.76 \\
\hline
\end{tabular}


Table 6. Disease susceptibility of 12 commercial and promising mango cultivars grown under different agroclimatic zones.

\begin{tabular}{|c|c|c|c|c|c|c|c|c|c|}
\hline \multirow{2}{*}{ Cultivar } & \multicolumn{3}{|c|}{ Anthracnose } & \multicolumn{3}{|c|}{ Floral malformation } & \multicolumn{3}{|c|}{ Stem-end-rot } \\
\hline & Akb & Chap & Gazi & Akb & Chap & Gazi & Akb & Chap & Gazi \\
\hline Ashwina & MS & MS & MS & LS & LS & LS & MS & MS & MS \\
\hline BARI Aam-1 & LS & LS & LS & LS & LS & LS & LS & LS & LS \\
\hline Bombai & LS & LS & LS & LS & MS & LS & LS & LS & LS \\
\hline Deori & LS & LS & LS & LS & LS & LS & LS & LS & LS \\
\hline Fazli & MS & MS & MS & LS & LS & LS & MS & MS & MS \\
\hline Gopalbhog & LS & LS & MS & LS & LS & LS & MS & LS & MS \\
\hline Kalia & LS & LS & LS & LS & LS & LS & LS & LS & LS \\
\hline Khirsapat & LS & LS & MS & LS & MS & LS & MS & LS & MS \\
\hline Langra & LS & LS & LS & LS & LS & LS & LS & LS & LS \\
\hline Lata Bombai & HS & MS & HS & HS & HS & HS & HS & LS & HS \\
\hline Rani Passand & LS & LS & LS & LS & LS & LS & LS & LS & LS \\
\hline Surjapuri & LS & LS & LS & LS & LS & LS & LS & LS & LS \\
\hline
\end{tabular}

LS: Less susceptible, MS: Medium susceptible, HS: Highly susceptible 
Table 7. Insect susceptibility of 12 commercial and promising mango cultivars grown under different agro-climatic zones.

\begin{tabular}{|c|c|c|c|c|c|c|c|c|c|}
\hline \multirow{2}{*}{ Cultivar } & \multicolumn{3}{|c|}{ Stem borer } & \multicolumn{3}{|c|}{ Fruit fly } & \multicolumn{3}{|c|}{ Fruit weevil } \\
\hline & Akb & Chap & Gazi & Akb & Chap & Gazi & Akb & Chap & Gazi \\
\hline Ashwina & LS & LS & LS & LS & LS & LS & LS & Absent & LS \\
\hline BARI Aam-1 & LS & LS & LS & LS & LS & LS & LS & Absent & LS \\
\hline Bombai & MS & LS & MS & LS & LS & LS & LS & Absent & LS \\
\hline Deori & LS & LS & LS & LS & MS & LS & LS & Absent & LS \\
\hline Fazli & MS & LS & MS & LS & LS & LS & LS & Absent & LS \\
\hline Gopalbhog & MS & LS & MS & LS & MS & LS & LS & Absent & LS \\
\hline Kalia & LS & LS & LS & LS & LS & LS & LS & Absent & LS \\
\hline Khirsapat & MS & LS & MS & MS & HS & MS & LS & Absent & LS \\
\hline Langra & MS & LS & MS & MS & MS & MS & LS & Absent & LS \\
\hline Lata Bombai & MS & LS & MS & MS & MS & MS & LS & Absent & LS \\
\hline Rani Passand & LS & LS & LS & LS & LS & LS & LS & Absent & LS \\
\hline Surjapuri & LS & LS & LS & LS & LS & LS & LS & Absent & LS \\
\hline
\end{tabular}

LS: Less Susceptible, MS: Medium susceptible, HS: Highly susceptible 
Table 8. Number and weight of fruits per plant of twelve commercial and promising mango cultivars grown under different agro-climatic zones of Bangladesh.

\begin{tabular}{l|c|c|c|c|c|c|c|c}
\hline \multirow{2}{*}{ Cultivars } & \multicolumn{4}{c|}{ No. of fruits per plant } & \multicolumn{3}{c}{ Wt. of fruits per plant } \\
\cline { 2 - 8 } & Akbarpur & Chapai & Gazipur & $\begin{array}{c}\text { Pooled } \\
\text { value }\end{array}$ & Akbarpur & Chapai & $\begin{array}{c}\text { Gazipur } \\
\text { value }\end{array}$ \\
\hline Ashwina & $165 \mathrm{bc}$ & $265 \mathrm{~b}$ & $132 \mathrm{~cd}$ & $188 \mathrm{bc}$ & $64.20 \mathrm{a}$ & $116.60 \mathrm{~b}$ & $41.51 \mathrm{~b}$ & $74.11 \mathrm{~b}$ \\
BARI Aam-1 & $147 \mathrm{~cd}$ & $244 \mathrm{bc}$ & $152 \mathrm{bc}$ & $181 \mathrm{~cd}$ & $23.77 \mathrm{de}$ & $49.27 \mathrm{de}$ & $22.95 \mathrm{e}$ & $32.00 \mathrm{def}$ \\
Bombai & $110 \mathrm{e}$ & $155 \mathrm{e}$ & $92 \mathrm{e}$ & $119 \mathrm{~g}$ & $29.17 \mathrm{~d}$ & $56.20 \mathrm{de}$ & $27.75 \mathrm{cde}$ & $37.71 \mathrm{~d}$ \\
Deori & $130 \mathrm{de}$ & $117 \mathrm{f}$ & $147 \mathrm{bc}$ & $131 \mathrm{fg}$ & $37.60 \mathrm{c}$ & $29.83 \mathrm{~g}$ & $40.18 \mathrm{~b}$ & $35.87 \mathrm{de}$ \\
Fazli & $129 \mathrm{de}$ & $200 \mathrm{~d}$ & $105 \mathrm{de}$ & $145 \mathrm{ef}$ & $64.70 \mathrm{a}$ & $129.88 \mathrm{a}$ & $56.25 \mathrm{a}$ & $83.61 \mathrm{a}$ \\
Gopalbhog & $152 \mathrm{~cd}$ & $211 \mathrm{~d}$ & $122 \mathrm{cde}$ & $162 \mathrm{de}$ & $19.83 \mathrm{ef}$ & $44.24 \mathrm{ef}$ & $29.12 \mathrm{cde}$ & $31.06 \mathrm{ef}$ \\
Kalia & $130 \mathrm{de}$ & $198 \mathrm{~d}$ & $153 \mathrm{bc}$ & $160 \mathrm{de}$ & $30.40 \mathrm{~d}$ & $49.63 \mathrm{de}$ & $32.82 \mathrm{c}$ & $37.62 \mathrm{~d}$ \\
Khirshapat & $206 \mathrm{a}$ & $222 \mathrm{~cd}$ & $190 \mathrm{a}$ & $206 \mathrm{ab}$ & $47.34 \mathrm{~b}$ & $57.63 \mathrm{~d}$ & $43.57 \mathrm{~b}$ & $49.51 \mathrm{c}$ \\
Langra & $182 \mathrm{ab}$ & $325 \mathrm{a}$ & $125 \mathrm{~cd}$ & $211 \mathrm{a}$ & $44.23 \mathrm{~b}$ & $79.41 \mathrm{c}$ & $29.71 \mathrm{~cd}$ & $51.14 \mathrm{c}$ \\
Lata Bombai & $106 \mathrm{e}$ & $134 \mathrm{ef}$ & $92 \mathrm{e}$ & $111 \mathrm{~g}$ & $16.66 \mathrm{f}$ & $24.85 \mathrm{~g}$ & $13.54 \mathrm{f}$ & $18.35 \mathrm{~g}$ \\
Rani Passand & $166 \mathrm{bc}$ & $201 \mathrm{~d}$ & $196 \mathrm{a}$ & $188 \mathrm{bc}$ & $26.27 \mathrm{de}$ & $35.91 \mathrm{fg}$ & $29.20 \mathrm{cde}$ & $30.46 \mathrm{ef}$ \\
Surjapuri & $153 \mathrm{~cd}$ & $191 \mathrm{~d}$ & $172 \mathrm{ab}$ & $172 \mathrm{~cd}$ & $27.60 \mathrm{~d}$ & $32.92 \mathrm{fg}$ & $24.13 \mathrm{de}$ & $28.22 \mathrm{f}$ \\
\hline Mean & 75.30 & 97.73 & 74.05 & - & 51.12 & 70.77 & 57.22 & 14.69 \\
CV (\%) & 9.99 & 8.13 & 7.97 & 8.72 & 13.46 & 11.68 & -
\end{tabular}




\section{References}

Anonymous. 2004. Survey and Monitoring of different Insects of Mango under different Agro-ecological conditions of Bangladesh. In: Mango Research and Development at BARI: a Scenario, Pomology Div, HRC, BARI. P.12.

BARC. 2005. Fertilizer Recommendation Guide-2005. Bangladesh Agricultural Research Council, Farmgate, Dhaka-1215. Pp. 16-31.

BBS. 2010. Yearbook of Agricultural Statistics of Bangladesh. Bangladesh Bureau of Statistics. Stat. Div. Ministry of Planning, Govt. of the People's Republic of Bangladesh. P.123.

Bhuyan, M. A. J. and M. S. Islam. 1989. Physio-morphological characters of some popular mango cultivars. Bangladesh J. Agric. 14(3): 181-187.

Bhuyan, M. A. J., M. N. Uddin, M. G. Mortuza, M. S. Islam and B. C. Sarker. 2003. Catalogue on Mango germplasm. HRC, BARI and IPGRI-ADB-TFT Project. Vol. 1. P. 117.

Castle, S.W. 1983. Growth, yield and cold hardiness of seven "Bears" Lemon trees on twenty seven rootstocks. Proc.Fla. State Hort. Soc. 96: 23-25.

Corbineau, F., M. Kante and D.Come.1986. Seed germination and seedling development in the mango (Mangifera indica L.). Tree Physiol. 1 (2):151-160.

Haque, A. M. M., M. R. Ali, M. R. Uddin and A. K. M. A. Hossain. 1993. Evaluation of elite mango cultivars at southern region of Bangladesh. Bangladesh J. Plant Breed. Genet. 6(2): 21-28.

Hossain, M. A., M. Rafiuddin, M. K. Hasan, P. K. Malaker and M. Ashraf Hossain. 2002. Morphological and physico-chemical studies of seventeen mango varieties. Bangladesh J. Agril. Res. 27(2): 273-281.

IBPGR.1989. Descriptors for Mango. International Board for Plant Genetic Resources. Rome, Italy. P.22

Karim, M. A. and H. U. Ahmed. 1989. A field guide on Insect pests and Diseases of mango in Bangladesh and their control. HRC, BARI and FAO/UNDP Mango Improvement and Development (BGD/81/022). 43 P.

Majumder, P.K. and D.K. Sharma. 1985. Mango. In: Fruits: Tropical and Subtropical. $3^{\text {rd }}$ edn. Vol. 1 (Eds. T.K. Bose and S.K. Mitra), Naya Prokash, 206 Bidhan Sarani, Kolkata, India. Pp.27.

Mukherjee, S.K. 1997. Introduction: botany and importance. In: The mango: Botany, Production and Uses.1st edn. (Ed. R. E. Litz), CAB International, Wallingford, UK. Pp. 1-19.

Saidha, T. and V.N.M. Rao. 1985. A rapid method for leaf area measurement in mango. Indian J. Hort. 42 (2): 71-73.

Valmayor, R. V. 1962. The mango, its Botany and Production. University of the Philippines, Los Banos, Laguna, the Philippines.

Whiley, A.W.1984. In: Tropical Tree Fruits for Australia (compiled by P. E. Page), Qd. Dept. Prim. Indus. Inform. Series Q183018. P. 25. 